Journal of Social Sciences 5 (4): 398-400, 2009

ISSN 1549-3652

(C) 2009 Science Publications

\title{
An Applied Using Local Wisdom to Making Ironware for Community Economic Development
}

\author{
${ }^{1}$ Chalor Yaekkhoksung, ${ }^{1}$ Songkoon Chantachon and ${ }^{2}$ Prasopsuk Ritthidet \\ ${ }^{1}$ Department of Cultural Science, Research Institute of Northeastern Arts and Culture, \\ Mahasarakham University, Thailand, 44150 \\ ${ }^{2}$ Department of Curriculum and Instruction, Faculty of Education, \\ Rajabhat Mahasarakham University, Thailand, 44000
}

\begin{abstract}
Problem statement: Arts and craft were important for economics and society of northeastern people in Thailand: For all that, local wisdom to make ironware lack interest from society. This research aimed to an applied using local wisdom to make ironware for community economic development. Approach: Research method was a qualitative research which studied populations who lived in 5 provinces: Khai village, Chaiyaphum; Pai village, Buriram province; Muang Wan village, Khonkaen province; Phon village, Sisaket province and Longtong village Nakhonratchasima province. 105 Populations were selected by purposive sampling from (1) key information group (2) causal informant group (3) general informants. Structured interview, unstructured interview, participant observation and descriptive analysis were used for research instruments. Results: The study found that (1) making ironware was an applied local wisdom which had local wisdom aspects which were conventional and newly integrated thoughts regarding tools, producing instruments, ways and products. (2) Government policy of a main approach and an alternative one emphasized on self-sufficiency which was a main factor for making ironware continuously till the present time. (3) Occupational crafts were products for usefulness and aesthetics that effected on households, depending on themselves. Conclusion: Local wisdom, making ironware was a producing way between man and man, man and supernatural, man and technology in globalization which was transmitted by any gurus. Local wisdom an applied continually helped local people existing peacefully, harmony with surrounding and belief: Accordingly, all communities could be self-sufficient and sharing things or products strongly.
\end{abstract}

Key words: Making ironware, community economic development, northeastern past of Thailand

\section{INTRODUCTION}

Making art and craft or ironware to apply for tools or equipments and weapons has been taking place in Thailand for a long time Even if, at the present, it still keeps on in many areas in all regions. Art and craft wares are divided into 2 types or follow: (1) Tools or equipments produced by heat method and strikingdigging tools, spade, knives, sickle and ax. (2) Wares produced scrupulously, silver bronze and neilo wares. In addition, there is molding metals to be material-ware and other things according to local designs ${ }^{[1]}$. Local arts and crafts of ironware are important occupations as well as agriculture, especially for people who are in rural areas and make a living with local art and craft works People without a growing season can serve their labors all year long, add up incomes for their family and raise more their life standard.
Local arts and crafts, making ironware in northeastern part of Thailand are very important for economics and society in this region because they will relieve unemployment of people in season in addition to adding their incomes ${ }^{[2]}$. Making ironware in northeastern part of Thailand is available in many areas, Muang Wan village, Muang wan sub-district, Namphong district, Khonkaen province; Nongkrabog village, Nakaew sub-district, Muang district, Sakolnakhon province; Nathon Village, Nathon subdistrict, Thatpharom district, Nakhonpranom province; Klangnoi village, Wan district, Thaboa district, Nongkhai province; Naleak village, Wansapung subdistrict, Wangsapung district, Loei province and Nongbuathong village, Nongbuathong sub-district, Muang district, Roiet Province. Making ironware in NongPhai and Tonpho villager, Thachang sub-district, NakhonLuang district, Ayuttaya province is very well-

Corresponding Author: Chalor Yaekkholsung, Faculty of the Research Institute of Northeastern Art and Culture, Mahasarakham University, Thailand, 44150 Tel: +66-43-741686 Fax: +66-43-741686 
known on behalf of Aranyik village. Because they are the largest places in Thailand and Continue there works over 200 years including with meticulous, durable, Quality and beautiful Knives ${ }^{[3]}$.

Seeing that Local wisdom of all communities in northeastern part of Thailand is lacking interest from people in Society, Communities that make a living with making iron ware are not supported to be real communal economics; therefore, this research focuses on Study of an applies using local wisdom to making ironware for community economic development for prominent and well-known products besides inheriting to next generations.

\section{MATERIALS AND METHODS}

This research used a qualitative research from populations in 5 Provinces: Bankhai Village, Chaiyaphum province; Pai village, Buriram province; Muangwan village, KhonKane province; Phon village, Sisaket province and Longtong village, Nakhonratchasima province. Populations were 105 persons who were selected by Purposive Sampling as following:

- Key informant group were 30 persons and could inform in depth regarding wisdom in striking metals, for example, government sector, private sector and Community sector

- Casual informant group were 50 persons; they were persons who related to striking metals-owners, blacksmiths and blacksmith club

- General informant group were people who live in and out communities, however relating to ironware, 20 persons

Instruments which collected data were structure interview except participant observation and data analysis was presented by descriptive analysis.

\section{RESULTS}

The research findings were found as follow:

- Making ironware or tools from metals was an applied local wisdom, which had originally local wisdom (old and new thoughts) in both equipments, tools, types and products. Cultureapplied theory could-be described that it was integrity and harmony between human life and environment thorough balance of relation system and culture of people in society, being unity, application, using, generating wisdom through analysis process, selecting competency of decision and selecting wisdom from ancestors to apply in any society and culture which all communities realized that they were properly: Firstly, local wisdom of a traditional approach was worshipping teacher before learning, respecting ghost, producing with equipments, typed and designs for amulets used for components in sacrifice rite to be fortune. Importance of local wisdom could apply for controlling man behavior in the same society and virtue of ancestors who passed away could decreased conflict and bias of humans in community and support social unique, custom and tradition thorough people way of life. Secondly, Integrity-local wisdom with traditional and new approaches was worshipping rite before learning and respecting to a teacher after learning successfully. Thirdly, local wisdom of a new approach was production with new technology to be convenience and Fast in Produce. In addition there were designs and various products thorough consumers' needs and highly competitive markets

- National development, on government policy of a major approach and an alternative one focused on economic developing and human oriented in development besides self. Sufficient development. They were main factors helping making ironware from local wisdom to be continuous till the present time. All products were supported by emphasizing on beauty, shape applying, designs, market system tool integration, transferring to others people, interested and sales promotion with arts and crafts exhibition of communities in any places

- Occupationally work products were products for utilization and aesthetics and resulted in households and communities earning income frequently through a community developing approach which people could be self-efficiency, an applied suitable technology tools, developed in to market systems to create power with production groups and suited for A National social and economic development plan of the 10th (20072011). This plan emphasized on human oriented to make people depend on themselves including with human quality development and Thai society to wisdom and learning society, in addition to creating strength of community and society to be a strong basis, adjusting economic structure to be balance and sustainable, developing among various natural, creating resources and environmental base 
security and strengthening moral principal in administration, management of country ${ }^{[4]}$

\section{DISCUSSION}

In community economic aspects and managing in making ironware, blacksmiths in 5 areas consisted of: Khai village, Chaiyaphum Province; Phai village, Buriram Province; Muangwan village, KhonKaen; Phon village, Seisaket Province; Longtong, Nakhonratchasima. Each area operated in household levels and in different incomes and applied local wisdom for production; moreover, they supported local economics to be distribution and self-efficiency in household levels ${ }^{[5]}$. Organizations were set to be productions and objects and could explain with function structure theory which stated that Society in certain borders was self-regulating or self-control with tendency of components which were self-dependence and Equilibrium in line with communal economics which people in community used or applied their knowledge to make a living in not only production but also distribution besides self-dependence. In order to operate production with plan and cooperation between producing groups that effected on groups' incomes that operated together in their daily life and communal economics that was strong enough to be selfdependence, There was self-sufficiency theory to explain sufficiency economy, as: (1) sufficiency is for all people and households but it was reckless economics. (2) Sufficient mind, helping others. (3) Sufficient environment, conserving and mounting Environment which was a basics of occupations. (4) Sufficient and strong community, assembling to solve any problems, for example, social, poverty and environment problems. (5) Sufficient wisdom, learning together to catch up with world changing. (6) Sufficient culture, on account of related economics and growing from cultural bases, meant that people's way of life related to environment and became secure economics. (7) Sufficient Security, It was not quickly changeable till humans could not accept.

\section{CONCLUSION}

Making ironware is competency of Thai, Laotian and Cambodians that is relayed for along time and various generations and, is production way which derived from relationship between man and man as well as man and supernatural. Man and technology in globalization obtain relaying from local gurus and also grouping or building chains is a main factor to develop potential of production from local wisdom in striking iron. Thus, there can be conclusion that self- dependency of community can't operate any activities alone. Each household must be dependable to one another to share thoughts, labors, material, or products; therefore, joining or building chains should start from men who are interested in simple Jobs to important ones till the many in communities, finally resulting in outside of communities in aspects of proceeding complete activities. Above all, any organizations which are the keys to community's development should study into communal people's needs and their contexts before proceeding development in order to meet communal people's needs.

\section{ACKNOWLEDGEMENT}

The researchers express their sincere appreciation for all of support provided and the referees for their helpful comments.

\section{REFERENCES}

1. Sati, P., J. Dhamawat, P. Pratepha and S. Rittidech, 2005. Changes in the conscious mind in applying technology for growing rice at the Chee River Basin in Northeastern of Thailand. J. Soc. Sci., 1: 172-177. http://www.scipub.org/fulltext/jss/jss13172-177.pdf

2. Nartsupha, C., 2003. The Thai village economy in the past. J. Econ. History, 63: 265-266. http://ideas.repec.org/a/cup/jechis/v63y2003i01p26 5-266_33.html

3. Wilart, P., N. Art and R. Prasopsuk, 2008. The social Adjustment of the Kuy People to a Multicultural context in southern Isan Thailand. J. Soc. Sci., 4: 343-346. http://www.scipub.org/fulltext/jss/jss44343346.pdf

4. Sata, W., V. Vinai., P. Bowjai and P. Rithidet, 2008. Environmental change of Lompao dam communities in Northeast Thailand. J. Soc. Sci., 4: http://www.scipub.org/fulltext/jss/jss44334337.pdf

5. Wongpongkam, N., S. Chantachon and S. Ieamvijarn, 2009. A study of Isan and Lao indigenous knowledge in Making Bronze and Brass Products for commercial purpose. Soc. Sci., 4: 191-195. http://www.medwelljournals.com/fulltext/TSS/200 9/191-195.pdf 